\title{
A Comparative Analysis of Job Stress Factors Affecting Work Life of Private vs Government College Teachers In Jodhpur and Ahmedabad
}

\author{
Quaita Joshi, \\ Student, St. Kabir Institute of Professional Studies, \\ Ahmedabad - 380054 \\ Email - quaita17@skips.in \\ Prof Anuradha Pandit, \\ Assistant Professor, St. Kabir Institute of Professional Studies, \\ Ahmedabad - 380054 \\ Email - anuradha@skips.in
}

\begin{abstract}
The modern day work environment has increasingly become more and more challenging with growing demands of employment and employees having to make the difficult choice of prioritizing home vs work. Job Stress is a major factor affecting working patterns of the modern day worker. And this factor has been seen as a major contributor in affecting employment especially for college teachers. In this study of the factors that are responsible for the job stress among the private and government college teachers have been studied. It has been found that there are various such factors that affect the life of the teachers in the colleges. Focus of this paper has been on the reasons behind the stressed stage that they suffer in their lives.

The objective of this study is to know the kind of stress teachers get at their jobs, to know the level of their stress and to find out the solution to this problem. The variables explored in this study are the job stress that teachers are exposed to and the factors that give rise to this stress are independent variables.

There are various factors that are proved as stressors for the teachers working in the government and private colleges like dealing with student discipline, larger classes/more students, teaching new courses, gender harassment, increased workloads and frequent changes to timetable, dealing with new education initiatives etc. So these are some the factors mentioned in the questionnaire to know the views of the teachers.
\end{abstract}

Key Words: Job Stress, Work Life Balance, Education 


\section{Introduction}

Society is made by the teachers that we have around us and the society is the only responsible for the disturbances that these teachers face in their lives due to the difficulties they face at their work. Teachers make students realise their dreams and reach their desired destinations. They are majorly responsible for the brightest future of students but still students keep criticizing them.

In this research study work has been done on the factors responsible for the job stress that teachers face at their work places and also suggestions have been made regarding possible solutions.

Stress at the workplace has been subjected to a larger amount of research studies in the past but shows no development or enrichment on the outcome. Medical practitioners agree that continuous and extensive stress within a person would lead to a monotonous life cycle affecting the physical conditions of the body, which in turn would tamper the physical health of the person leading to mental disorders and agony. Different occupations face different types of stresses and different kinds of job profiles also face serious and varied stresses. Work overload has been the predominant stressor in the teaching field. A study to analyze and evaluate the level of job satisfaction and level of stress becomes the need of the hour to analyze the factors that cause hindrances to the teachers in their job and also validate them with proper remedial measures to ensure that the job profile of the teachers make them satisfied with the job so that the stressors or the stress factors are under control.

Stress for teachers is a growing concern, as they incessantly adhere to long working hours and conditions of overwork, unpredictable and the fear of safety of job, low morale and motivation leading to dissatisfaction in job and lack of authority and responsibilities in roles of decision making. These factors contributing to workplace stress has proved to have a detrimental effect on the health conditions, both mentally and physically thereby affecting the wellbeing of teachers. This leads to the negative impact on workplace productivity affecting the development and the progress of the workplace. Teaching as an occupation is regarded as a noble profession but it requires increasing the mental abilities due to an overwhelming and cut-throat competition which sometimes becomes highly tedious. Increasing consciousness for education due to increasing competitions among students for achieving their goals adds more pressure and stress on teachers. This so called 'Noble' profession creates leaders, scientists, philosophers, advocates, politicians and administrators. In the educational set up, secondary school teachers must be aware of developments in their subject area, new resources, methods and national objectives. Secondary education differs from the other levels, where teachers have to be more specialized and the organization is consequently more complex. Since work division is more pronounced, issues of coordination become more important which gives rise to stress. The root cause as well as solution of the problem must be looked after.

The aim of this study was to examine the level of job satisfaction and investigate the reasons of job stress in teachers of Private and Government Colleges (Male and Female). 


\section{Objectives of the study}

- To know the kinds of stress teachers get at their jobs

- To know the level of stress teachers get at private colleges and government colleges

- To research upon the solution to it

\section{Scope of the topic/study}

The present research basically covered all the major factors that affect the work life of government and private college teachers and also the solutions to it. For this research project data was collected from Jodhpur and Ahmedabad college teachers and analysis done on the whole data accordingly

\section{Rationale}

The purpose of this study is to know about the factors that majorly affect the work life of private and government college teachers. Data says that by 2020 the major cause behind the early deaths of the people would be the stress or depression that they get at their job places. So it is necessary to know about the stressors that disturb the lives of those who make this society literate i.e. our teachers. There are various factors that are responsible for the stress situation among teachers but majorly there were 12 factors in this study and a few of those are long working hours, larger classes, teaching new courses, dealing with new education initiatives, gender harassment, frequent changes to timetable etc.

So this study majorly speaks about the various stressors for the college teachers and also the solution to it.

\section{Review of literature}

Arlene Gray Blix, Robert J. Cruise, Bridgit McBeth Mitchill and Glen G. Blix (1994) in their paper talked about the symptoms of occupational stressors in university teachers, which were burnout, stress related health problems, perceived work stress, productivity, job satisfaction and consideration for job change. Three motivational styles and corresponding job rewards were measured using some instruments and this was all done to see the fit between motivational style and job rewards at workplace. Female teachers' scores showed a higher level of misfit between these two in comparison with males. Female teachers were more likely to consider job change as a result of job stress. This researched study concluded that the heavy workload is the most frequently cited reason behind the change of job by any teacher in the colleges. The kind of pressure that teachers face in the universities make them change the job, otherwise such stressors throw them into the stage of burnout.

In the year 1995 R.T. Pithers, G.J. Fogarty also talked about the occupational stress. They came up with a test instrument that was developed at that time to measure stress- Occupational 
stress Inventory (OSI). This instrument measures occupational stress, strain and coping resources. Using the OSI, the researchers obtained data from a group of vocational teachers and compared to a group of professional non-teachers. Overall the results showed a significantly higher level of stress among teachers, although only one of 10 stress and strain measures contributed to this effect. The implications of the results in the occupational role for teachers, were discussed.

In the same year Gregory J. Boyle, Mark G. Borg, Joseph M. Falzon and Anthony J. Baglioni Jr. (1995) worked upon the stress level of primary school teachers. They took a survey in the Mediterranean islands of Malta and Gozo where they received the responses from 710 primary school teachers to measure the job satisfaction and career commitment. The survey showed that there are four dimensions behind the stress of teachers and those are - Pupil misbehavior, Time/Resource Difficulties, Professional Recognition Needs, and Poor Relationships. The results revealed the hypothesis on the affecting factors (sources of stress) for teachers and gave evidence of additional stress factor (Workload). Work load and misbehavior showed by students are the most common stressors for teachers.

When most researchers were talking about the reasons of stress and the measures to be adopted to know the reasons behind the work stress of teachers, Sarbjit Kaur and Dinesh Kumar (2008) worked upon a comparative study between the working of government and nongovernment college teachers in order to know who are satisfied with their job and who are experiencing stress. The authors found after conducting a survey on 200 college teachers both government and non-government from Bathinda district, that government college teachers are more satisfied with their working conditions than non-government college teachers and nongovernment teachers experience more stress than the government teachers at their job.

Increasing competition in the market also increases job stress at managerial levels and that needs to be controlled. Looking at this, which was the same case in Malaysia too where the competition in the market was really being the major issue for teachers Nilufar Ahsan, Zaini Abdullah, David Yong Gun Fie and Syed Shah Alam (2009) researched on the relationship between job satisfaction and job stress. The determinants of job stress examined under this study include, management role, relationship with others, workload pressure, homework interface, role ambiguity, and performance pressure. The results of this research point out that job stress and job satisfaction share a significant negative relationship.

In the coming years there are many authors who worked upon the reasons behind the motivation of people at workplace in order to make them more productive and goal oriented. A study related to this was conducted by Thomas and Kennedy Andrew (2010). They worked upon the relationship between work motivation and job satisfaction. They worked with a sample size of 417 from three different types of schools. Results indicated a significant relationship between work motivation and job satisfaction of teachers. A significant difference in motivation scores of secondary school teachers as per differences in their job satisfaction was observed. Further, no significant differences were found between work motivation and gender, age, marital status and teachers working in different types of school management. The results are discussed in terms of implications for secondary schools and future research. 
Ana Sliskovic and Darja Maslic Sersic (2011) did a study on work stress among university teachers considering the gender and position differences. Their sample size was 1,168 and the survey was done in Croatia's universities. In that survey they took all the positions of college staff in consideration and both the genders. 57\% percent of the sample were women. Results showed that women have greater stress than men. Also it showed that assistant professor, associate professor and full professors reported greater stress related to material and technical work condition than assistant but assistant then had greater stress level in relation with the colleagues. The study showed that job stress varies from gender to gender and profile to profile.

In 2012 G. Lokanadha Reddy and R. Poornima did a research on job stress and professional burnout. They talked about how various occupational stressors that make the life of university teachers difficult and full of stress and till today there have no such measures been taken which can completely beat the job stress of teachers. Occupational stressors result in organizational inefficiency, high staff turnover, absenteeism due to sickness, decreased quality, and quantity of practice, increased costs of health care, and decreased job satisfaction.

Hassan Danial Aslam (2013) wrote a paper to explore the stressors of teachers, level stress and the ways of minimizing the stress among teachers. The study involved the sample size of 400 university teachers from various universities and both, quantitative and qualitative techniques were used to gather the data. Results of this study showed that the main stressors for teachers were lack of cooperation among the teachers in the universities and planning a new lesson to teach every day in the class. Government college teachers feel more stress while planning a new lesson every day.

Several researchers researched upon the level of stress among the teachers of different departments like arts, science etc. Muthu kumar K. (2014) examined the factors causing stress, outcomes of stress and coping strategies adopted by the Government Aided and Self Financing Arts and Science College Teachers of Chennai to overcome stress. Based on the 360 samples collected from within Chennai corporation limit the researcher tried to enhance the knowledge of stress experience and its impact on the Arts and Science College teachers. In order to trace the truth and bring out the hidden facts on stress in higher education profession and its impact on Arts and Science College teachers the survey was conducted among different levels of college teachers belonging to different socio economical background by way of distributing structured questionnaire in person directly.

Sofie Masuku and Stella Muchenwa (2015) in Zimbabwe worked upon occupational stress among university teachers to explore stress levels, symptoms, and common stressors for lecturers at a Christian university in Zimbabwe. A modified University and College Union model stress questionnaire was distributed to 36 full-time lecturers at the university. Findings revealed that most common stressors were increased workloads, need to hit targets/deadlines, and long working hours. Finally, there was no significant difference in responses when it comes to gender, age, faculty, as well as workload. This research contradicted the result of an earlier research which claimed that the stress level is different among different genders and different profiles. Dr. Savita Gahlawat (2017) worked upon occupational stress and job satisfaction among 
government and private college teachers with sample size 100 (50 government and 50 private college teachers) of age 25-35 years. The result showed that the level of stress in private college teachers is high in comparison with government college teachers while government college teachers have higher job satisfaction than the private college teachers have.

Private college teachers are facing a great amount of occupational stress these days and that can result in a very dangerous situation. Dr. Naresh Gandhi (2017) researched upon a comparison of job stress of female teachers working in colleges of Punjab and Rajasthan state. The aim of this study was to know about if there is any difference in stress for female teachers working in colleges in different states. The sample size was of 200 teachers from the random colleges in Punjab and Rajasthan state and OSI test instrument was used for the investigation. The results showed that there is no difference as such in job stress of female teachers working in colleges of Punjab and Rajasthan state.

Pijus Kanti Bhuin(2017) conducted his study specifically for the teachers and administrators of West Bengal. Survey was conducted using a validated stress scale among the teachers and academic administrators of private educational institutes in West Bengal, India. Results revealed that nearly one third of the respondents are exposed to high stress zone. The situation is alarming, not parlous though. ANOVA results showed that age, experience and area of residence are most powerful endogenous factor in differentiating work-groups in respect to stress. Gender, income, job status and educational qualifications have comparatively lower influences. Interestingly, teachers and administrators do not differ themselves significantly so far workrelated stress is concerned. Harish K A and B Jeya Prabha(2018) in their study worked majorly upon the occupational stressors that make the life of teachers difficult and also the impact of these stressors upon occupational stress and job satisfaction. Heavy workload, unsecured state of job, low pay emoluments, lack of career development, lack of communication, harassments in the school or college by peer teachers/workers/students/others, family and financial problems are some of the stressors that have been stated in this research paper.

\section{Research Gap}

The gap that would be there in this study is that no researcher as such has talked in depth about the solution to the job stress problem at the colleges and has not researched upon the solution to it. So, further scope of study is on what are the various solutions that can be proved as the most helpful for releasing the job stress among college teachers.

\section{Research method used}

The research method used here is Descriptive Method because we worked upon job stress among college teachers and stress is the thing that cannot be questioned that why the stress is there in this job. Stress arises when a person cannot handle a particular situation and hence cannot be questioned. Also we did an in-depth study upon the factors and solution to the job stress among teachers. Data source used was Primary source. This study was based on questionnaires and personal interviews only and no previous records were taken into consideration. That's why 
Primary Source of information is only there. Sampling was done using Stratified Sampling Method. The sample size kept was of 60 in which 30 questionnaires were got filled from Jodhpur teachers and another 30 were from Ahmedabad teachers.

Hypothesis and statistical tools -Chi square test

(i) H0: Job stress among teachers is independent of sectors

Ha: Job stress among teachers is dependent of sectors

(ii) H0: Job stress in teachers is independent of gender Ha: Job stress in teachers is dependent of gender

Data Analysis and Interpretation

1. Table 1. Cities from where data was collected:

\begin{tabular}{|c|c|}
\hline City Name & Respondents \\
\hline Ahmedabad & 30 \\
\hline Jodhpur & 30 \\
\hline
\end{tabular}

For this study we kept the sample size of 60 and in which we kept 30 for Jodhpur and 30 for Ahmedabad, so this table represents the responses that we've received $50 \%$ from both the cities.

\section{Table 2- Gender of respondents:}

\begin{tabular}{|c|c|}
\hline Gender & Respondents \\
\hline Male & 30 \\
\hline Female & 30 \\
\hline
\end{tabular}

The data that we collected is $50 \%$ from male and another $50 \%$ from female teachers

3. Table 3- Sector wise distribution of Respondents:

\begin{tabular}{|c|c|}
\hline Sector & Respondents \\
\hline Private & $56.7 \%$ \\
\hline Government & $43.3 \%$ \\
\hline
\end{tabular}

The collected data is from both the sectors i.e. from the private as well as the government sector. The responses that we got are $56.7 \%$ from the private sector and the remaining $43.3 \%$ is from the government sector. 


\section{Table 4- Occupation of Respondents}

\begin{tabular}{|c|c|}
\hline Teaching Staff & Responses \\
\hline Yes & $91.7 \%$ \\
\hline No & $8.3 \%$ \\
\hline
\end{tabular}

The majority of the data is collected from the teaching staff which is $91.7 \%$ and the remaining responses are from the non-teaching staff too and that makes $8.3 \%$ of the total responses.

\section{Table 5-Job Satisfaction}

\begin{tabular}{|c|c|}
\hline Satisfied with Job & Responses \\
\hline Yes & $93.3 \%$ \\
\hline No & $6.7 \%$ \\
\hline
\end{tabular}

$93.3 \%$ of the teachers say that they are satisfied with their job and only $6.7 \%$ of the teachers say that are just not satisfied with their job.

6. Table 6- Matching of Skills, knowledge and experience with job requirements

\begin{tabular}{|c|c|}
\hline $\begin{array}{c}\text { Skills, knowledge and } \\
\text { experience match the } \\
\text { requirements of the job }\end{array}$ & Responses \\
\hline Yes & $88.3 \%$ \\
\hline No & $11.7 \%$ \\
\hline
\end{tabular}

$83.3 \%$ of the teachers say that their skills, knowledge and experience match the requirements of their job while $11.7 \%$ of the teachers said that their job requirements do not match the skills or experience that they have, which shows that they are liable to do other tasks also that do not match their skills.

\section{Table 7- Opinion about right workload}

\begin{tabular}{|c|c|}
\hline Right Workload & Responses \\
\hline Yes & $65 \%$ \\
\hline No & $35 \%$ \\
\hline
\end{tabular}

According to $65 \%$ of respondents the workload at their job places is just about right while other $35 \%$ of the respondents said that no the workload is just too much and is above a limit. 
8. Table 8- Opinion about whether deadlines/targets given are reasonable and achievable

\begin{tabular}{|c|c|}
\hline $\begin{array}{c}\text { Deadlines/targets given are } \\
\text { reasonable and achievable }\end{array}$ & Responses \\
\hline Yes & $71.7 \%$ \\
\hline No & $28.3 \%$ \\
\hline
\end{tabular}

Majority of the respondents said that the targets are achievable and reasonable while $28.3 \%$ of the respondents said that no, the targets and deadlines are just not achievable and reasonable and even it raises the state of stress in them.

9. Table 9- Opinion about whether work is appreciated and seen as valuable

\begin{tabular}{|c|c|}
\hline $\begin{array}{c}\text { Work is appreciated and } \\
\text { seen as valuable }\end{array}$ & Responses \\
\hline Yes & $85 \%$ \\
\hline No & $15 \%$ \\
\hline
\end{tabular}

Majority (85\%) of the teachers said that they find their work to be appreciated mostly but $15 \%$ of the respondents said that their work is just not appreciated and not seen as valuable.

10. Table 10- Opinion about appreciation for work done affecting performance.

\begin{tabular}{|c|c|}
\hline $\begin{array}{c}\text { No appreciation for work done affects } \\
\text { the performance }\end{array}$ & Responses \\
\hline Strongly Agree & $46.7 \%$ \\
\hline Agree & $26.7 \%$ \\
\hline Neutral & $21.7 \%$ \\
\hline Disagree & $1.7 \%$ \\
\hline Strongly Disagree & $3.3 \%$ \\
\hline
\end{tabular}

Here, $46.7 \%$ of the respondents strongly agree that no appreciation for work done affects the performance, $26.7 \%$ of the respondents agree, $21.7 \%$ of the respondents neither agree nor disagree, $1.7 \%$ of them disagree while $3.3 \%$ of the respondents strongly disagree with this statement

11. Table 11- Job stress is the result of ignoring the factors that are responsible for it.

\begin{tabular}{|c|c|}
\hline $\begin{array}{c}\text { Job stress is the result of ignoring } \\
\text { the factors that are responsible } \\
\text { for it }\end{array}$ & Responses \\
\hline Strongly Agree & $36.7 \%$ \\
\hline
\end{tabular}




\begin{tabular}{|c|c|}
\hline Agree & $31.7 \%$ \\
\hline Neutral & $25 \%$ \\
\hline Disagree & $5 \%$ \\
\hline Strongly Disagree & $1.7 \%$ \\
\hline
\end{tabular}

$36.7 \%$ of the respondents strongly agree with the statement while $31.7 \%$ of the people agree, $25 \%$ of the respondents are neutral with this and $5 \%$ were disagreeing with this and the remaining $1.7 \%$ of the respondents said that they strongly disagree with the statement.

12. Table 12- Relation between Job Stress in teaching profession and work load.

\begin{tabular}{|c|c|}
\hline $\begin{array}{c}\text { Job stress is the result of ignoring } \\
\text { the factors that are responsible } \\
\text { for it }\end{array}$ & Responses \\
\hline Strongly Agree & $35 \%$ \\
\hline Agree & $26.7 \%$ \\
\hline Neutral & $20 \%$ \\
\hline Disagree & $15 \%$ \\
\hline Strongly Disagree & $3.3 \%$ \\
\hline
\end{tabular}

$35 \%=$ strongly agree, $26.7 \%=$ agree, $20 \%=$ neither agree nor disagree, $15 \%=$ disagree and $3.3 \%=$ strongly disagree.

\section{Figure 1- Which Are the Most Common Factors (Stressors) That Cause Job Stress to Lecturers?}

60 responses

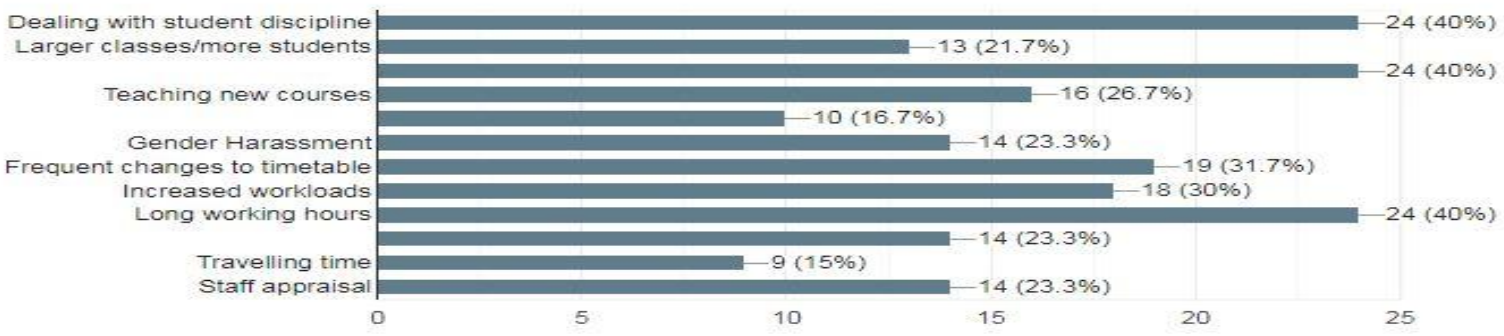

\section{Interpretation}

In this study we kept 12 factors that majorly cause job stress among the teachers and the results of this show that majority of the teachers believe that the most common stressors for them are Dealing with student discipline, dealing with aggressive/violent behavior of students, long working hours and frequent changes to time table while the least common stressors are travelling time, dealing with new education initiatives and larger classes/more students. 


\section{Table 13- Relation between Job Stress at colleges and situation of burst out}

\begin{tabular}{|c|c|}
\hline $\begin{array}{c}\text { Job Stress given in the } \\
\text { colleges may result in the } \\
\text { situation of burst out }\end{array}$ & Responses \\
\hline Yes & $55 \%$ \\
\hline No & $45 \%$ \\
\hline
\end{tabular}

\section{Interpretation}

Burst out is the situation where stress level crosses a certain amount of it. Now according to this research study $55 \%$ of the teachers in the colleges believe that yes Job Stress that is given them in the college may result in the situation of burst out while the another $45 \%$ of the respondents stated that No, the teaching stress is not that kind of stress which can result in the situation of burst out. So the responses show a very less difference between the yes and no of the respondents.

\section{Data Analysis}

Hypothesis 1 - H0: Job stress among teachers is independent of gender

Ha: Job stress among teachers is dependent of gender

Gender * Job Stress in teaching profession increases when work load increases Cross tabulation

Count

\begin{tabular}{|c|c|c|c|c|c|c|}
\hline & \multicolumn{5}{|c|}{$\begin{array}{l}\text { Job Stress in teaching profession increases when work load } \\
\text { increases }\end{array}$} & \multirow[t]{2}{*}{ Total } \\
\hline & 1 & 2 & 3 & 4 & 5 & \\
\hline & 12 & 10 & 5 & 3 & 0 & 30 \\
\hline venuer & 9 & 6 & 7 & 6 & 2 & 30 \\
\hline Total & 21 & 16 & 12 & 9 & 2 & 60 \\
\hline
\end{tabular}

Chi-Square Tests

\begin{tabular}{|l|r|r|r|}
\hline & \multicolumn{1}{|c|}{ Value } & Df & \multicolumn{1}{|c|}{$\begin{array}{c}\text { Asymp. Sig. } \\
(2 \text {-sided })\end{array}$} \\
\hline Pearson Chi-Square & $4.762^{\mathrm{a}}$ & 4 & .313 \\
Likelihood Ratio & 5.568 & 4 & .234 \\
Linear-by-Linear & 3.414 & 1 & .065 \\
Association & 60 & & \\
N of Valid Cases & & & \\
\hline
\end{tabular}




\section{Interpretation}

Sig value should be less than 0.05 but here the sig value is greater than this and therefore $\mathrm{H} 0$ is accepted which says that job stress is independent of gender and hence it cannot be said that job stress in more among males only or females only, rather it is independent of gender

Hypothesis 2 -H0: Job stress in teachers is independent of sector

Ha: Job stress in teachers is dependent of sector

\begin{tabular}{|c|c|c|c|c|c|c|}
\hline \multicolumn{7}{|l|}{ Count } \\
\hline & \multicolumn{5}{|c|}{$\begin{array}{c}\text { Job Stress in teaching profession increases when work load } \\
\text { increases }\end{array}$} & \multirow[t]{2}{*}{ Total } \\
\hline & 1 & 2 & 3 & 4 & 5 & \\
\hline \multirow{3}{*}{$\begin{array}{l}\text { Sector } \\
2 \\
\text { Total }\end{array}$} & 10 & 7 & 7 & 8 & 2 & 34 \\
\hline & 11 & 9 & 5 & 1 & 0 & 26 \\
\hline & 21 & 16 & 12 & 9 & 2 & 60 \\
\hline
\end{tabular}

Chi-Square Tests

\begin{tabular}{|l|r|r|r|}
\hline & Value & Df & \multicolumn{1}{|c|}{$\begin{array}{c}\text { Asymp. Sig. } \\
\text { (2-sided) }\end{array}$} \\
\hline Pearson Chi-Square & $7.136^{\mathrm{a}}$ & 4 & .129 \\
Likelihood Ratio & 8.534 & 4 & .074 \\
Linear-by-Linear & 5.303 & 1 & .021 \\
Association & 60 & & \\
N of Valid Cases & & \\
\hline
\end{tabular}

Interpretation - Sig value should be less than 0.05 but here the sig value is greater than this and therefore $\mathrm{HO}$ is accepted which says that job stress is independent of sector and hence it cannot be said that it is more in private sectors only or in government sectors only, rather it is independent of the sector.

\section{Reliability}

\section{Case Processing Summary}

\begin{tabular}{|ll|r|r|}
\hline & & \multicolumn{1}{|c|}{$\mathrm{N}$} & \multicolumn{1}{c|}{$\%$} \\
\hline \multirow{4}{*}{ Cases } & Valid & 60 & 100.0 \\
& Excluded & 0 & .0 \\
& Total & 60 & 100.0 \\
\hline
\end{tabular}




\begin{tabular}{|r|c|r|}
\hline \multicolumn{3}{|c|}{ Reliability Statistics } \\
\begin{tabular}{|r|c|} 
Cronbach's \\
Alpha
\end{tabular} & $\begin{array}{c}\text { Cronbach's } \\
\text { Alpha Based } \\
\text { on } \\
\text { Standardized } \\
\text { Items }\end{array}$ & \\
\hline .430 & .317 & \\
\hline
\end{tabular}

Theoretical Connect -Job stress is the hottest issue these days in any sector. Every person at every level is suffering from job stress these days due to some or the other reasons. Various researchers have researched upon this topic and founded out that the major cause of a person's depression now - a - days is the stress that they get at their work places. Work stress can result in a great amount of mental and physical illness for any person. Too much of stress given at job places can even result in the situation of burst out too. Researchers have found that teaching is the profession where a great amount of stress is found which is not seen or noticed generally because teaching as a profession is not taken as that hectic but actually it is the most difficult job to perform in which one needs to handle various kinds of students at the same time. Theory says that various factors are there which create stress among the teachers in college and major among them are gender harassment, large classrooms, long working hours, new education system etc.

The topic which was studied upon is not novel. Many researchers have studied upon this but the present research focusses only upon the college teachers and also researched upon the solution to it. So, all the theories say yes there is a great amount of stress at every job these days and the practical world research exactly match with these theoretical concepts that we study in books.

\section{Findings}

The findings from this research study are that there are various factors which disturb the life of a teacher but the major factor among those is to handle the students' discipline. These days teachers face this problem the most because gone are the days when students used to be very obedient towards their teachers and no thought of disrespecting them were there in the mind of students but nowadays no respect for the teachers has left in the students and this has become the major issue for teachers in order to handle them and to make them study well.

Also the education system has so changed that every now and then some new things get added to the course and this gets proved to be the most hectic thing for the teachers to keep themselves updated and to teach the students the new things but by making themselves prepared first.

Other than this what it has been found out is that the female teachers mostly face the harassment problem at their workplace and this is the major cause of stress among females. $23.3 \%$ of female teachers selected this option as the most common stressor for them. Then long working hours also make them feel so stressed because they just don't get any time left for other work. 
Frequent changes in time table is also a big stressor for the college teachers as they prepare in advance about what to be taught in a particular session but a sudden change in that cause stress in order to get the topic prepared on the spot to teach their students.

Other than these another major issue for the teachers is large classrooms and too many students. Earlier this was not the case when limited number of students only got admission but now to manage and teach too many students is a very stressful task for majority of the teachers.

This study says that mostly the non-teaching staff of the college is found to be the satisfied with their job; it is the teaching staff who are satisfied generally due to too much of work pressure and no appreciation or may be due to some other reasons.

Other than this it has also been found out that the non-teaching staff of the college believe that dealing with the students' discipline, long working hours, students' violence, long travelling hours are the main stressors for them.

So, these are the major findings from this project which states that this is really a very serious issue for this country to handle because in India a huge amount of people are in teaching profession. Data says that teachers are suffering from job stress and this problem needs to be solved because research says that by 2020 the major cause behind deaths of people will be the depression that they face and job stress is the main factor due to which people suffer from depression. Also job stress is not dependent of any sector or any gender. This study says that people working in any sector, either private or government, face equal amount of job stress. Also it is not dependent of any gender because the result says that male and female, both suffer from job stress in their teaching profession.

So, this study clearly figures out that the job stress among teachers is really a very serious matter and needs to get resolved in order to keep the education imparting public of our country safe and stress free.

\section{Recommendations}

After analyzing the whole data of results, it is recommended that this matter should be taken very seriously and the problems, the stress, the misbehavior that the teachers of our society facing are required to be resolved soon before burst out occurs for an individual.

Some solutions for this problem can be-

- Paid holidays should be granted to teaching staff so that they can also enjoy their family time and can get release from work stress for a few days at least.

- Strict action should be taken if any student misbehaves in any way with any teacher. This will make other students to be in discipline.

- Cameras should be fitted everywhere in the college so that if anyone tries to harass any male or female staff member that can get captured immediately and strict action can be taken against the person. This will make teachers to feel safe while working. 
- Proper transport facility should be provided to the teachers also, so that those who suffer from the long distance travelling problem can get bus facilities.

- No sudden changes should be made in time table because this causes a great amount of stress among teachers in order to teach students without any prior reading.

- Strength of the class should be less. This ensures teachers keep a complete hold over the class and give complete attention to every student.

- If some innovation in the existing education system takes place or if something new gets added to the course then proper study material should be provided to the teachers where they can get the complete knowledge from and hence no stress situation arises.

This is a very serious issue, so some correct actions and solutions for this problem should soon be provided for our teachers.

\section{Bibliography}

1. Blix, A. G., Cruise, R. J., Mitchell, B. M., \& Blix, G. G. (1994). Occupational stress among university teachers. Educational Research, 36(2), 157-169.

2. Pithers, R. T., \& Fogarty, G. J. (1995). Symposium on Teacher Stress. British Journal of Educational Psychology, 65(1), 3-14.

3. Boyle, G. J., Borg, M. G., Falzon, J. M., \& Baglioni, A. J. (1995). A structural model of the dimensions of teacher stress. British Journal of Educational Psychology, 65(1),49-67.

4. Nagra, S. (n.d.). Comparative study of government and non-government college teacher in relation to job satisfaction and job stress.

5. Abdullah, Z., Ahsan, N., \& Alam, S. S. (2009). The Effect of Human Resource Management Practices on Business Performance among Private Companies in Malaysia. International Journal of Business and Management, 4(6).

6. Andrew, T. \& K (2010). Work Motivation and Job Satisfaction of Teachers

7. Slišković, A., \& Seršić, D. (2011). Work Stress among University Teachers: Gender and Position Differences. Archives of Industrial Hygiene and Toxicology, 62(4).

8. Reddy, G. L., \& R., Poornima. (2012.). Occupational Stress and Professional Burnout of University Teachers in South India.

9. Hassan, A. D. (2013). Exploring Stress Factors among College Teachers of Pakistan.

10. Muthukumar, K. (2014.). A comparative study on the level of stress among government aided and self-financing arts and science college teachers. Retrieved from http://shodhganga.inflibnet.ac.in/bitstream/10603/45208/1/01_title.pdf

11. Masuku, S., \& Muchenwa, S. (2015). Occupational Stress among University Lecturers: A Case of Zimbabwe. 